\title{
Analisis Struktur Batin Puisi Sesamar Kasih Pencari Rezeki Karya Dwi Ayu Utami Nasution
}

\author{
Sri Kurnia Hastuti Sebayang \\ Dosen STKIP Budidaya Binjai \\ Email :hastutisrikurnia@gmail,com
}

\begin{abstract}
Abstrak
Puisi nama menggunakan bahasa yang bervariasi dan menjadikan isi lebih menarik bagi pembaca karya sastra untuk mengetahui lebih dalam makna yang ingin disampaikan oleh pengarang yang terdapat dalam karyanya tersebut. Puisi sebagai karya sastra menggunakan bahasa sebagai media untuk mengungkapkan makna. Dalam hal ini pengamatan atau pengkajian terhadap puisi khususnya dilihat dari gaya bahasanya sering dilakukan. Peneliti memilih puisi nama sebagai objek studi kajian puisi. Pemilihan puisi namaini didasarkan pada struktur batin dan struktur fisik puisi yang menarik untuk dikaji lebih jauh. Puisi tersebut mengandung maksud kompleksitas berkaitan dengan bahasanya yang ingin disampaikan oleh pengarang. Sepengetahuan penulis belum ada yang mengkaji baik dari aspek bahasa yang digunakan, maka hal tersebut menjadi penting untuk dikaji. Alasan tersebut yang mendorong penulis untuk mengadakan penelitian tentang bahasa yang digunakan pengarang dalam menyampaikan makna dan pesan cerita untuk mengkaji unsur fisik dan unsur batin dari puisi sebuah nama.
\end{abstract}

Kata kunci: struktur batin dan puisi

\section{Pendahuluan}

Sastra merupakan wujud gagasan seseorang melalui pandangan terhadap lingkungan yang berada di sekelilingnya dengan menggunakan bahasa yang indah. Sastra adalah bentuk seni yang diungkapkan oleh pikiran dan perasaan manusia dengan keindahanbahasa.

Menurut Hudson (dalam Tarigan 2009:10), sastra merupakan pengungkapan baku dari peristiwa yang telah disaksikan orang dalam kehidupan, yang telah direnungkan, dan dirasakan orang mengenai segi-segi kehidupan yang menarik minat secara langsung dan kuat dari seorang pengarang atau penyair. Sastra hadir sebagai hasil perenungan pengarang terhadap fenomena yang ada.Sastra tidak saja dinilai sebagai sebuah karya seni yang memiliki budi, imajinasi, dan emosi.Akan tetapi, sastra telah dianggap sebagai suatu karya kreatif yang dimanfaatkan sebagai konsumsi intelektual di samping konsumsi emosi.

Karya sastra adalah wujud permainan kata-kata pengarang yang berisi maksud tertentu, yang akan disampaikan kepada penikmat sastra. Karya sastra merupakan luapan 
perasaan pengarang yang dicurahkan dalam bentuk tulisan, menggunakan kata-kata yang disusun sedemikian rupa.Karya sastra adalah wacana yang khas yang di dalam ekspresinya menggunakan bahasa dengan memanfaatkan segala kemungkinan yang tersedia (Sudjiman 1993:7).Secara singkat dapat dikatakan bahwa bahasa merupakan wahana ekspresi dalam karya Sastra.Bahasa memiliki pesan keindahan sekaligus membawa makna dalam karya sastra.

Medium utama sastra adalah bahasa, sastra tercipta dari rangkaian kata- kata dan katakata itu sendiri merupakan bagian dari bahasa.Bahasa merupakan bahan mentah sastrawan.Karya sastra hanyalah seleksi beberapa bagian dari suatu bahasa tertentu, seperti halnya patung dapat dianggap sebagai sebongkah marmer yang dikikis sedikit bagianbagiannya (Wellek 1989:217).

Menggunakan bahasa untuk menyampaikan gagasan dan imajinasi dalam proses penciptaan karya sastra sangat diperlukan oleh setiap pengarang. Hal ini menyiratkan bahwa karya sastra merupakan peristiwa bahasa (Sudjiman 1993:1).Dengan demikian, unsur bahasa merupakan sarana yang penting dan diperhitungkan dalam penyelidikan suatu karya sastra, karena bahasa berfungsi untuk memperjelas makna dan menambah keindahan karya sastra.

Bahasa berperan dalam menentukan nilai suatu karya sastra (Suharianto 1982:21). Bahasa menjadi jembatan utama yang menghubungkan dunia pengarang dengan pembacanya. Isi yang baik belum merupakan jaminan bagi berhasilnya suatu karya sastra, bila tidak dijalin dengan bahasa yang baik.Bahasa sastra lebih bersifat khas (Wellek 1989:15).Bahasa sastra penuh ambiguitas, homonim, dan sangat konotatif, sedangkan bahasa ilmiah cenderung menyerupaisistematika atau logika simbolis dan bersifat denotatif.Maka tidak mengherankan jika bahasa sastra bersifat menyimpang dari kaidahkaidah ketatabahasaan.

Sastra dan bahasa merupakan dua bidang yang tidak dapat dipisahkan. Hubungan antara sastra dengan bahasa bersifat dialektis (Wellek 1989:218).Keistimewaan pemakaian bahasa dalam karya sastra sangat menonjol karena salah satu keindahan suatu karya sastra dapat dilihat dari bahasanya.Tanpa keindahan bahasa, karya sastra menjadi hambar.Keistimewaan bahasa dalam karya sastra terjadi karena adanya kebebasan penyair atau pengarang dalam menggunakan bahasa atau pengarang mempunyai maksud tertentu. Kebebasan seorang sastrawan untuk menggunakan bahasa yang menyimpang dari bentuk aturan konvensional guna menghasilkan efek yang dikehendaki sangat diperbolehkan. 
Dalam memilih penggunaan bahasa, sastrawan dapat memilih antara, (1) mengikuti kaidah bahasa secara tradisional konvensional, (2) memanfaatkan potensi dan kemampuan bahasa secara inovatif, atau (3) menyimpang dari konvensi yang berlaku (Sudjiman1993:19-20).

Dalam penciptaan karya sastra tak pernah terlepas dari penggunaan gaya bahasa. Sangat mustahil bila sebuah karya sastra lahir tanpa adanya keterlibatan atau keterkaitan dengan penggunaan gaya bahasa. Sehingga semakin pekat penggunaan gaya bahasa dalam sastra, semakin terasa pula nilai estetik yang terkandung di dalamnya.

Dalam mengkaji bahasa di dalam karya sastra perlu menggunakan kajian puisi karena kajian puisi merupakan suatu kajian yang menelaah berbagai aspek puisi. Kajian puisi adalah telaah secara mendalam terhadap puisi atau karya sastra yang terdiri dari rangkaian kata kata pilihan, indah, menawan, menyentuh hati dan mengandung makna mendalam dengan memperlihatkan unsur - unsur puisicitraan puisi dan objek analisis lain sesuai kebutuhan dan tujuankajian puisi agar tercipta proses penjiwaan dan penghayatan serta terbentuk dan kepekaan dan kecintaan terhadap puisi sebagai karya sastra.

Pembagian karya sastra yang telah dikenal ada tiga, prosa, puisi, dan drama.Semua jenis sastra itu menggunakan kata-kata yang indah supaya menarik.Persamaan pokok ketiganya adalah menggunakan bahasa sebagai sarana penyampaiannya.

Menurut Sherlley (dalam Pradopo 2010:6), puisi merupakan rekaman detik-detik yang paling indah dalam hidup kita. Puisi adalah sintesis dari berbagai peristiwa bahasa yang telah tersaring semurni-murninya dan berbagai proses jiwa yang mencari hakikat pengalamannya, tersusun dengan sistem korespondensi dalam salah satu bentuk. Menurut Shahnon Ahmad (dalam Pradopo 2010:6), menyimpulkan unsur puisi yang paling pokok adalah (1) pemikiran, ide, dan emosi, (2) bentuknya, dan (3) kesan yang dibiaskan oleh ide dalam puisi.

Puisi sebagai karya sastra menggunakan bahasa sebagai media untuk mengungkapkan makna. Dalam hal ini pengamatan atau pengkajian terhadap puisi khususnya dilihat dari gaya bahasanya sering dilakukan. Pengamatan terhadap puisi melalui pendekatan struktur untuk menghubungkan suatu tulisan dengan pengalaman bahasanya disebut kajian stilistika.

Puisi nama merupakan suatu karya sasta dimana penulis mengartikan nama dirinya untuk mengungkapkan jati diri, mengungkapkan arti sebuah nama atau hanya sebuah tulisan pengekspresian diri yang dibuat sang penulis dengan menggambarkan suasana hati penulis atau pun kenyataan hidup penulis. Dimana puisi nama memberikan kenyataan spiritual kepada pembaca, membagikan sebuah keluh, kesah kepada pembaca untuk berbagi kisah 
hidup. Puisi nama juga ditulis dengan menggunakan bahasa - bahasa yang khas.

Puisi nama menggunakan bahasa yang bervariasi menjadikan isi lebih menarik bagi pembaca karya sastra untuk mengetahui lebih dalam makna yang ingin disampaikan oleh pengarang yang terdapat dalam karyanya tersebut. Peneliti memilih puisi nama sebagai objek studi kajian puisi. Pemilihan puisi nama ini didasarkan pada unsur batin dan unsur fisik puisi yang menarik untuk dikaji lebih jauh. Puisi tersebut mengandung maksud kompleksitas berkaitan dengan bahasanya yang ingin disampaikan oleh pengarang.Sepengetahuan penulis belum ada yang mengkaji baik dari aspek bahasa yang digunakan, maka hal tersebut menjadi penting untuk dikaji. Alasan tersebut yang mendorong penulis untuk mengadakan penelitian tentang bahasa yang digunakan pengarang dalam menyampaikan makna dan pesan cerita untuk mengkaji unsur fisik dan unsur batin dari puisi sebuah nama.

Penelitian ini menggunakan teori yang relevan untuk mendukung analisis yang akan dicapai. Teori-teori yang digunakan sebagai berikut.

\section{a. Kajian Puisi}

Kajian puisi terbagi menjadi dua kata yaitu kajian dan puisi. Pembahasan pertama diawali denganmenganalisa pengertian kajian. Pembahasaan kedua akan merangkum tentang puisi dan pembahasan terahir adalah kesimpulan tentang pengertian kajian puisi.

\section{b. GayaBahasa}

Gaya bahasa adalah cara pemakaian bahasa dalam karangan, atau bagaimana seorang pengarang mengunkapkan sesuatu yang akan dikemukakan. Style (gaya bahasa) menyarankan pada pemakaian bahasa dalam konteks tertentu, oleh pengarang tertentu, dan untuk kajian tertentu.

Menurut Satoto (2012:150), gaya adalah cara mengungkapkan diri sendiri, entah melalui bahasa, tingkah laku, berpakaian, dan sebagainya. Gaya merupakan perwujudan penggunaan bahasa oleh seorang penulis untuk mengemukakan gambaran, gagasan, pendapat, dan membuahkan efek tertentu bagi penanggapnya sebagaimana cara yang digunakannya (Aminuddin 1995:1). Sebagai wujud cara menggunakan kode kebahasaan, gaya merupakan relasional yang berhubungan dengan rentetan kata, kalimat, dan berbagai kemungkinan manifestasi kode kebahasaan sebagai sistem tanda. 
Menurut Muljana (dalam Pradopo 2010:93), gaya bahasa adalah susunan perkataan yang terjadi karena perasaan yang timbul atau hidup dalam hati penulis, menghidupkan kalimat dan memberi gerak pada kalimat. Gaya bahasa tersebut untuk menimbulkan reaksi tertentu dan menimbulkan tanggapan pikiran kepada pembaca.

Gaya bahasa adalah bahasa indah yang digunakan untuk meningkatkan efek dengan jalan memperkenalkan serta membandingkan suatu benda atau hal tertentu dengan benda atau hal lain yang lebih umum (Tarigan 2009:4). Gaya bahasa merupakan bentuk retorik, yaitu penggunaan kata-kata dalam berbicara atau menulis untuk meyakinkan atau mempengaruhi penyimak dan pembaca.

Gaya bahasa dapat digunakan dalam segala ragam bahasa baik ragam lisan, tulis, nonsastra, dan ragam sastra, karena gaya bahasa adalah cara menggunakan bahasa dalam konteks tertentu oleh orang tertentu untuk maksud tertentu (Sudjiman 1993:13). Akan tetapi, secara tradisional gaya bahasa selalu ditautkan dengan teks sastra, khususnya teks sastra tertulis. Gaya bahasa mencakup diksi atau pilihan leksikal, struktur kalimat, majas dan citraan, pola rima, dan matra yang digunakan seorang sastrawan atau yang terdapat dalam sebuah karyasastra.

Menurut Endraswara (2008:72), bahasa sastra adalah bahasa khas. Khas karena bahasanya telah direkayasa dan dipoles sedemikian rupa. Dari polesan itu kemudian muncul gaya bahasa yang manis. Dengan demikian, seharusnya pemakaian gaya bahasa harus didasari penuh oleh pengarang. Bukan hanya suatu kebetulan gaya diciptakan oleh pengarang demi keistimewaan karyanya. Jadi dapat dikatakan jika pengarang pandai bersilat bahasa, kaya kata, dan mahir dalam menggunakan gaya bahasa maka karyanya akan semakin mempesona dan akan lebih berbobot. Pemilihan bentuk bahasa yang digunakan pengarang akan berkaitan fungsi dan konteks pemakaiannya. Pemakaian gaya dalam sastra selalu dikaitkan dengan konteks yang melatar belakangi pemilihan dan pemakaian bahasa. Semua gaya bahasa itu berkaitan langsung dengan latar sosial dan kehidupan dimana bahasa itudigunakan.

Menurut Abrams (dalam Nurgiyantoro 2010:276), gaya bahasa (stile) adalah cara pengucapan bahasa dalam prosa atau seorang pengarang mengungkapkan seseuatu yang ingin dikemukakan. Stile ditandai oleh ciri-ciri formal kebahasaan seperti pilihan kata, struktur kalimat, bentuk-bentuk bahasa figuratif, penggunaan kohesi, dan lain-lain. 
Dari beberapa beberapa uraian tersebut, dapat disimpulkan bahwa gaya bahasa adalah bahasa khas pengarang dalam karya sastra. Gaya bahasa dapat membuat karya sastra lebih hidup dan bervariasi serta dapat menghindari hal-hal yang bersifat monoton yang dapat membuat pembaca bosan. Unsur gaya bahasa terdiri atas fonologi, sintaksis, leksikal, dan retorika (berupa karakteristik penggunaan bahasa figuratif, pencitraan, dan sebagaianya).

\section{c. Diksi}

Diksi merupakan unsur leksikal dalam gaya bahasa (Nurgiyantoro 2010:290). Diksi mengacu pada pengertian penggunaan kata-kata tertentu yang sengaja dipilih oleh pengarang.Mengingat karya sastra adalah dunia kata, komunikasi dilakukan dan ditafsirkan lewat kata-kata. Pemilihan kata-kata

Tersebut tentunya melewati pertimbangan-pertimbangan tertentu untuk memperoleh efek ketepatan dan efek keindahan. Efek itu sendiri secara sederhana dapat dipertimbangkan dari segi bentuk dan makna untuk mendukung estetis karya sastra yang bersangkutan, mampu mengkomunikasikan makna, pesan, dan mampu mengungkapkan gagasan yang dimaksudkan oleh pengarang. Pemilihan kata dalam hal itu disebut dengan diksi.

Pemilihan kata dalam karya sastra adalah cara penggunaan kata-kata dalam teks sastra sebagai alat untuk menyampaikan gagasan dan nilai estetis tertentu (Aminudin 1995:201). Pilihan kata atau diksi tidak hanya mempersoalkan ketepatan pemilihan kata, tetapi juga merusak yang ada (Keraf2008:24).

Diksi atau pemilihan kata mengacu pada penggunaan kata-kata tertentu yang sengaja dipilih dan digunakan oleh pengarang. Mengingat bahwa karya sastra adalah dunia dalam kata, komunikasi dilakukan dan ditafsirkan lewat kata- kata. Pemilihan kata-kata tentunya melalui pertimbangan-pertimbangan tertentu untuk mendapatkan efek yang dikehendaki (Nurgiyantoro 2010:290).

Pengarang pada hakikatnya bermaksud menyampaikan perasaan dan pikirannya dengan setepat-tepatnya seperti yang dialami batinnya.Selain itu, pengarang juga ingin menggambarkan pengalaman jiwanya. Menurut Barfield (dalam Pradopo 2010:54), bila kata-kata dipilih atau disusun dengan cara yang sedemikian rupa hingga artinya menimbulkan imajinasi estetik, maka diksi yang demikian itu disebut diksi puitis.

Diksi atau pilihan kata sesungguhnya sangat menentukan dalam penyampaian makna suatu karya sastra (Sudjiman 1993:22).Kata, rangkaian kata, dan pasangan kata yang dipilih dengan seksama dapat menimbulkan pada diri pembaca suatu efek yang ingin dikehendaki pengarang.Misalnya menonjolkan bagian tertentu suatu karya, menggugah simpati atau 
empati pembaca, atau pun menghilangkan monotoni.Untuk mencapai efek tertentu dapat digunakan sarana fonologis, gramatikal, atau leksikal. Sangatlah penting diketahui kata dan ungkapan atau butir leksikal mana yang sebaiknya digunakan dalam konteks tertenu agar informasi yang hendak disampaikan atau kesan yang hendak ditimbulkan terwujud.

Masalah pemilihan kata menurut Champan (dalam Nurgiyantoro 2010:290) dapat melalui pertimbangan-pertimbangan formal tertentu.Pertama, pertimbangan fonologis, misalnya kepentingan alitrasi, irama, dan efek bunyi tertentu.Kedua, pertimbangan dari segi metode, bentuk, dan makna yang dipergunakan sebagai sarana mengkonsentrasikan gagasan.Masalah konsentrasi ini penting sebab yang membedakannya dengan stile bahasa nonsastra.Pemilihan kata dalam sastra dapat saja berupa kata-kata kolonial sepanjang mampu mewakili gagasan.Dalam hal ini, faktor personal pengarang untuk memilih kata-kata yang paling menarik perhatiannya berperan penting.Pengarang dapat saja memilih kata atau ungkapan tertentu sebagai siasat untuk mencapai efek yangdiinginkan.

Dari beberapa uraian tersebut, dapat disimpulkan bahwa diksi adalah pilihan kata yang dipergunakan pengarang untuk menyampaikan gagasan dan makna dalam karya sastra.Dalam karya sastra penggunaan diksi atau pilihan kata sangat beragam.Hal ini mungkin disengaja oleh pengarangnya untuk keindahan sastra itu sendiri.

Dengan demikian, persoalan diksi sebenarnya jauh lebih luas dari apa yang dipantulkan oleh jalinan kata-kata itu, karena tidak sekadar untuk memilih kata- kata mana yang dipilih untuk mengungkapkan keindahan dan membentuk gaya ekspresi gagasan atau ide yang tepat yang menyangkut masalah frase, gaya bahasa, dan uangkapan. Fungsi diksi adalah sebagai sarana mengaktifkankegiatanberbahasa (komunikasi) yang dilakukan seseorang untuk menyampaikan maksud dan gagasannya kepada orang lain.

Menurut Supriyanto (2011:33), penyimpangan dalam pemilihan kata dapat ditemukan pemanfaatan kosakata dari beberapa bahasa. Penyimpangan tersebut pemilihan kata dalam karya sastra seperti pemanfaatan kosakata bahasa daerah (Jawa, Sunda, Minangkabau, dan sebagainya), pemanfaatan kosakata bahasa asing (Arab, Inggris, Mandarin, Belanda, dan sebagainya), dan pemanfaatan sinonim.

\section{d. Majas}

Majas sering dianggap sebagai sinonim dari gaya bahasa, namun sebenarnya majas termasuk dalam bagian gaya bahasa. Majas merupakan unsur- unsur penunjang gaya bahasa (Ratna 2009:164). Dengan kata lain gaya bahasa lebih luas 
daripada majas. Majas sudah berpola, sehingga pola-pola majas seolah- olah membatasi kreatifitas.

Majas adalah bahasa kiasan yang dapat menghidupkan atau meningkatkan efek dan menimbulkan konotasi tertentu.Majas dapat dimanfaatkan oleh para pembaca atau penulis untuk menjelaskan gagasan mereka (Tarigan 1985:179). Majas memiliki keindahan bahasa tersendiri, karena majas merupakan gaya bahasa dalam bentuk tulisan maupun lisan yang dipakai dalam suatu karangan yang bertujuan untuk mewakili perasaan dan pikiran dari pengarang. Dari keindahan gaya bahasa yang dipakai, majas merupakan bentuk sebuah ungkapanperasaandaripengarang.

Menurut Abrams (dalam Nurgiyantoro 2010:296), retorika dalam unsur stile meliputi penggunaan bahasa figuratif dan wujud pencitraan.Bahasa figuratif tersebut dapat dibedakan ke dalam permajasan (figuratife of thought) dan penyiasatan struktur (figure of speech). Menurut Nurgiyantoro (2010:297), permajasan (figure of thought) merupakan teknik pengungkapan bahasa, penggaya bahasaan yang maknanya tidak menujuk pada makna harfiah kata-kata yang mendukung, melainkan pada makna yang ditambah dan makna yang tersirat. Majas merupakan gaya yang sengaja mendayagunakan penuturan dengan memanfaatkan bahasa kias. Majas dengan figuran bahasa yaitu penyusunan bahasa yang bertingkat-tingkat atau berfiguran sehingga memperoleh makna yang kaya (Waluyo1995:83).

Penggunaan bentuk-bentuk bahasa kiasan dalam kesusatraan merupakansalah satu bentuk penyimpangan kebahasaan, yaitu penyimpanganmakna. Memahami pengungkapan-pengungkapan bahasa kiasmemerlukan perhatian tersendiri, khususnya untuk menangkap pesan yang dimaksudkan oleh pengarang.

Pengungkapan gagasan dalam dunia sastra, pengarang ingin menyampaikan sesuatu secara tidak langssung, banyak menyalahgunakan pemakaian bentukbentuk bahasa kias. Pemakaian bentuk-bentuk tersebut untuk membangkitkan suasana tertentu, tanggapan indra tertentu, dan untuk memperindah penuturan. Bahasa kias menunjang tujuan-tujuanestetis penulisan karya sebagai karya seni.

Bentuk pengungkapan yang mempergunakan bahasa kias (majas) jumlahnya relatif banyak (Nurgiyantoro 2010:298). Pemilihan dan penggunaan bentuk kiasan bisa saja berhubungan dengan selera, kebiasaan, kebutuhan, dan kreatifitas 
pengarang. Bentuk-bentuk permajasan yang banyak digunakan oleh pengarang adalah bentuk persamaan atau perbandingan, yaitu membandingkan sesuatu dengan sesuatu yang lain melalui ciri-ciri kesamaan antara keduanya, ciri- ciri fisik, sifat, sikap, keadaan, suasana, keadaan, tingkah laku, dan sebagainya.

Fungsi majas untuk menciptakan efek yang lebih kaya, lebih efektif, dan lebih sugestif dalam karya sastra. Menurut Pradopo (2010:62), majas menyebabkan karya sastra menjadi menarik perhatian, menimbulkan kesegaran, lebih hidup, dan menimbulkan kejelasan gambaran angan.

Dari beberapa beberapa uraian tersebut, dapat disimpulkan bahwa majas adalah bahasa kiasan yang digunakan pengarang di dalam karya sastra dengankesan tertentu untuk mewakili gagasan yang ingin disampaikan. Majas dapat membuat karya sastra lebih hidup dan bervariasi serta dapat menghindari hal-hal yang bersifat monoton yang dapat membuat pembaca bosan.

\section{e. Citraan}

Citraan adalah kesan yang dapat kita tangkap (terima) pada kalimat/ baris dalam puisi. Citraan berhubungan dengan indra manusia. Adapun Macammacam citraan puisi ialah sebagai berikut :

1. Citraan penglihatan

Yaitu, citraan yang memberikan rangsangan kepada indra penglihatan sehingga hal-hal yang tidak terlihat seolah-olah terlihat.

2. Citraan pendengaran

Yaitu citraan yang dihasilkan dengan menyebutkan atau menggunakan bunyi suara.

\section{Citraan taktil}

Yaitu, citraan yang ditimbulkan gambar angan yang dapat dihayati dengan indra peraba/perasaan.

4. Citraan penciuman

Yaitu, citraan yang ditimbulkan gambaran angan indra pencium.

5. Citraan gerak 
Yaitu, citraan yang menggambarkan sesuatu yang sesungguhnya tidak bergerak tetapi dilukiskan dapat bergerak.

6. Citraan pengecapan

Yaitu, citraan yang menggunakan gambaran angan indra pengecap.

\section{f. Unsur intrinsik dan ekstrinsik puisi}

Unsur intrinsik dan ekstrinsik merupakan unsur pembangun didalam karya sastra termasuk juga puisi. Unsur intrinsik merupakan unsur terpenting didalam puisi karena unsur intrinsik merupakan unsur yang berada didalam cerita seperti tema, amanat, tokoh dan penkohan, dan sebagainya begitupun sebaliknya.

\section{Metode Penelitian}

Penelitian ini merupakan penelitian deskriptif kualitatif. Penelitian kualitatif adalah metode yang digunakan untuk menelitu pada kondisi objek yang alamiah, dimana peneliti hanya sebagai instrument kunci, teknik pengumpulan data dilakukan secara triangulasi (gabungan), analisis data bersifat induktiflkualitatif, dan hasil penelitian lebih menekankan makna daripada generalisasi.

\section{Hasil dan Pembahasan}

Hasil dan Pembahasan pada penelitian ini adalah sebagai berikut :

\section{SESAMAR KASIH PENCARI REZEKI}

Karya : Dwi Ayu Utami Nasution

D = Disaat masalah terus menerus menghampiri

$\mathbf{W}=$ Wadah mengaduku adalah ayah

I = Indah hatinya menjelma dalam angan

A = Air mata selalu menetes melihat jerih payahnya

$\mathbf{Y}=$ Yang tak terbayang betapa letihnya ia

$\mathbf{U}=$ Usianya yang tak muda lagi, namun ia sangat bersemangat dan gigih dalam bertanggung jawab

$\mathbf{U}=$ Usaha yang ia lakukan tak sesuai dengan energinya

$\mathbf{T} \quad=$ Tapi demi keluarga, jiwa raga rela ia pertaruhkan

A = Apapun dilakukan agar sandang pangan tepenuhi

M = Meskipun lelah, namun ia tak menghiraukannya

I = Inilah yang akan menjadi inspirasi motivasiku 


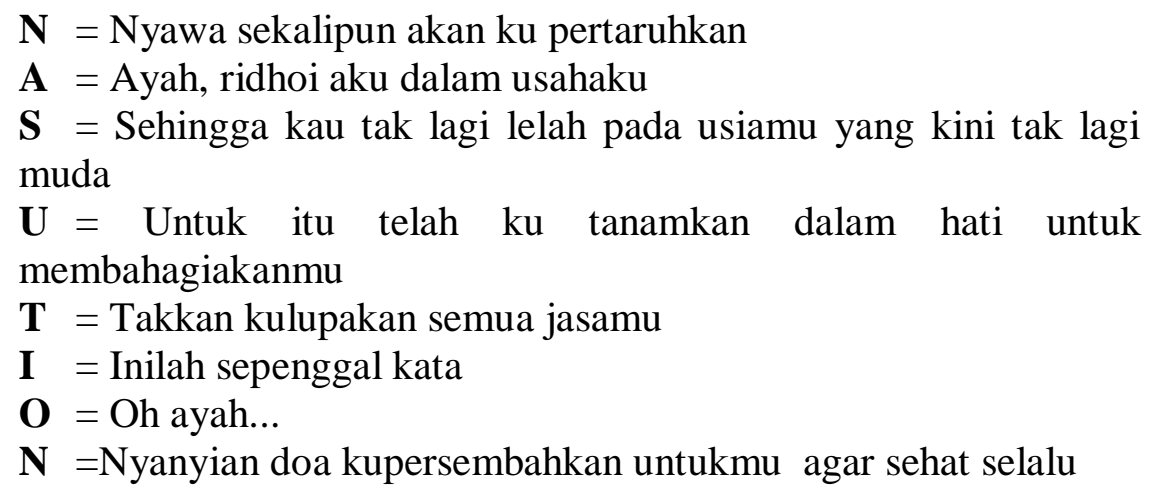

\section{Unsur Batin Puisi}

1. Tema : Kekaguman seorang anak kepada ayahnya

2. Amanat : 1. Hargailah setiap usaha orang tua

2. Sayangilah orang tua dengan semestinya

3. Jadilah anak yang berbakti

4. Jadilah anak yang dapat membahagiakan orang tua

\section{Citraan :}

1. Penglihatan (mata)

a. Bait 1 baris ke 2 pada kata "ayah"

b. Bait 2 baris ke 2 pada kata "air mata"

c. Bait 2 baris ke 3 pada kata "tak muda lagi"

d. Bait 3 baris ke 1 pada kata "usaha yang ia lakukan"

e. Bait 3 baris ke 2 pada kata "demi keluarga"

f. Bait 3 baris ke 3 pada kata "sandang pangan"

2. Pendengaran

a. Bait 4 baris ke 2 pada kata "ayah, ridhoi aku dalam usahaku"

b. Bait 4 baris ke 3 pada kata "sehingga kau tak lagi lelah"

c. Bait 4 baris ke 7 pada kata "oh, ayah"

d. Bait 4 baris ke 8 pada kata "nyanyian doa"

3. Penciuman

Tidak ada

4. Perasaan

a. Bait 2 baris ke 1 pada kata "jerihnya"

b. Bait 2 baris ke 2 pada kata "letihnya"

c. Bait 2 baris ke 3 pada kata "semangat"

d. Bait 3 baris ke 2 pada kata "pertaruhkan"

e. Bait 3 baris ke 4 pada kata "lelah" 
f. Bait 4 baris ke 1 pada kata "nyawa"

g. Bait 4 baris ke 4 pada kata "membahagiakanmu"

h. Bait 4 baris ke 5 pada kata "jasamu"

5. Suasana/situasi

a. Baris pertama kata "disaat masalah terus menerus" suasana sedih

b. Baris kedua kata "wadah tempat mengadu" suasana damai

c. Baris ketiga kata "indah hatinya" suasana damai

d. Baris keempat kata "air mata selalu menetes" suasana sedih

e. Baris kelima kata "betapa letihnya ia" suasana sedih

f. Baris keenam kata "semangat dan tanggung jawabnya luar biasa" suasana kagum

g. Baris ketujuh kata "usaha yang ia lakukan tak sesuai dengan energinya" suasana sedih

h. Baris kedelapan kata "tapi demi keluarga, jiwa raga rela ia pertaruhkan" suasana kagum

i. Baris kesembilan kata "apapun dilakukannya" suasana kagum

j. Baris kesepuluh kata "meskipun lelah, ia tak menghiraukannya" suasana kagum

k. Baris kesebelas kata "inspirasi motivasiku"suasana semangat

1. Baris kedua belas kata "nyawa sekalipun akan kupertaruhkan" suasana

semangat

m. Baris ketiga belas kata "ridhoi aku dalam usahaku" suasana berharap

n. Baris keempat belas kata "sehingga kau tak lagi lelah" suasana sedih

o. Baris kelima belas kata "telah kutanamkan dalam hati untuk membahagiakanmu" suasana semangat

p. Baris keenam belas kata "takkan kulupakan semua jasamu" suasana mengingat

q. Baris kesembilan belas kata "nyanyian doa" suasana berharap

\section{Suasana atau situasi}

Suasana yang akan disampaikan oleh penyair ialah sedih dan kagum melihat perjuangan seorang ayah kepada keluarganya. Dalam lelah, ia masih mau mendengarkan curahan hati anaknya dan berusaha membuat anaknya senang dan selasai pada masalah yang dihadapi anaknya. Sesungguhnya penyair juga merasakan apa yang dirasakan oleh sang ayah tersebut, yaitu lelah namun sang ayah tidak pernah 
mengeluh dengan kondisi yang dialaminya. Oleh karena itu, sang anak bermotivasi untuk dapat menjadi orang yang sukses sehingga dapat menggantikan sang ayah agar tidak bekerja lagi dengan usianya yang tidak muda lagi.

\section{Kesimpulan}

Puisi adalah sebuah karya sastra yang terdiri dari rangkaian kata - kata pilihan, indah, menawan, menyentuh hati dan mengandung makna mendalam . kata - kata yang terangkai menyatu menjadi larik - larik puisi terangkai menjadi bait - bait puisi. Lalu, kumpulan bait bait puisi tersebut mengandung rima, mewakili satu tema, dan jika dibaca dengan penuh penghayatan maka akan melahirkan suasana yang berbeda - beda serta mengandung nasehat dan amanat yang tersirat dan beragam, bergantung pada daaya tangkap pembaca terhadap ungkapan rasa penyair/ pencipta puisi dalam proses apresiasi puisi.

Sebagai sorang pelajar khususnya pelajar bahasa dan sastra indonesia dapat aktif dalam segala hal termasuk memaknai atau melukiskan namanya sendiri kedalam kata - kata yang indah, karena melukiskan nama melalui puisi memiliki nilai tersendiri yang lebih indah karena kita dapat memaknai arti sebuah nama, melukiskan keluh kesah melalui sebuah nama, dan sebagainya.

\section{DAFTAR PUSTAKA}

Nurgiyantoro, Burhan. 2000. Teori Pengkajian Fiksi Yogyakarta: Gajah Mada University Press

Sudjiman, Panuti. 1986. Kamus Istilah Sastra. Jakarta:Gramedia

Wellek, Rene dan Austin Warren. 1995. Teori Kesusastraan. Jakarta: Gramedia (diIndonesiakan oleh Melani Budianta)

Wicaksono andri. 2016. Pengkajian Prosa Fiksi .www.inirumahpintar.com 